\title{
ПРАВОВИЙ СТАТУС ОСВІТНЬОГО ОМБУДСМЕНА В УКРАЇНІ
}

\author{
Рябовол Л. Т.
}

\section{ВСТУП}

Пріоритетним у діяльності демократичної, правової, соціальної держави $\epsilon$ гарантування прав, свобод та законних інтересів людини і громадянина, створення належних умов для їх реалізації кожним. На забезпечення цього держава формує правозахисний механізм, одним 3 обов'язкових складників якого $є$ омбудсмен. Як указують Ю. Тодика і О. Марцеляк, поява цього інструменту $\epsilon$ наслідком усвідомлення суспільством важливості гарантій, у тому числі інституційних, захисту прав і свобод" Нині омбудсмен постає як інституційно-організаційна гарантія прав та свобод людини і громадянина в усіх демократичних державах, а також на наднаціональному рівні.

Омбудсмен принципово відрізняється від інших складників правозахисного механізму за своїм державно-громадським статусом, поєднанням рис державного органу і суспільної/громадської інституції. Його важливе соціальне призначення полягає у тому, що як посередник між особою та державою він сприяє підвищенню рівня довіри громадян до органів державної влади, загалом демократизації суспільного життя.

У нашій державі починаючи з 1998 р. діє Уповноважений Верховної Ради України з прав людини, який здійснює парламентський контроль за додержанням конституційних прав та свобод людини і громадянина. Продовжує формуватися мережа спеціалізованих омбудсменів, призначення яких полягає у захисті прав та свобод особливих категорій осіб. Нині ця мережа охоплює Уповноваженого Президента України з прав дитини, Раду бізнес-омбудсмена, Уповноваженого Президента України з прав людей 3 інвалідністю, Урядового уповноваженого 3 питань гендерної політики, Уповноваженого із захисту державної мови. Належне місце в ній посів і освітній омбудсмен, на якого покладено виконання завдань щодо захисту права на освіту/прав у сфері освіти. Роль освітнього омбудсмена $€$ суттєвою не лише у межах держави, але й поза нею. Так, ефективність цієї посадової особи у сприянні виконанню Україною міжнародних зобов'язань щодо додержання прав людини на освіту дає змогу підтримувати високий авторитет нашої держави у міжнародному співтоваристві.

\footnotetext{
${ }^{1}$ Тодика Ю.Н., Марцеляк О.В. Інститут омбудсмена: світові моделі і досвід. Вісник Академї правових наук Украӥни. 2008. № 2(13). С. 59.
} 
Правовий статус освітнього омбудсмена можна розглядати у двох аспектах: 1) як сукупність нормативно-правових актів, якими визначено місце і роль цього інституту у державному механізмі; 2) як сукупність сутнісних ознак цього інституту - мети, завдань, принципів діяльності, порядку призначення та звільнення з посади, організаційної структури, функцій та повноважень, порядку взаємодії з органами державної влади, інститутами громадянського суспільства, міжнародними організаціями, які діють у сфері захисту прав людини загалом і права на освіту зокрема, відповідальності за порушення законодавства й невиконання посадових обов'язків.

\section{1. Правові засади інституту освітнього омбудсмена}

Право на освіту - особливе право, реалізація якого має велике значення для розвитку держави, суспільства, людства. У зв'язку з цим як саме право на освіту, так i його суб'єкти потребують додаткового захисту, забезпечення якого покладається на відповідного спеціалізованого омбудсмена. До прикладу, в США інститут університетського омбудсмена було впроваджено наприкінці $60-\mathrm{x}$ років XX століття 3 метою врегулювання розбіжностей і вирішення конфліктів, які можуть виникати за участю студентів та професорсько-викладацького складу. Американські дослідники цього питання вважають, констатує I. Хомишин, що університет - ідеальне місце для впровадження інституту омбудсмена, оскільки наукові працівники та студенти $є$ найбільш прогресивною частиною суспільства, водночас в університеті як у великому системному утворенні може виникати значна кількість конфліктів ${ }^{2}$.

У світовій практиці накопичено значний досвід діяльності омбудсмена 3 питань освіти (освітнього, шкільного, студентського, університетського омбудсмена). Нині такий інститут є невід'ємним складником правозахисного механізму США, Великої Британії, Канади та інших країн. Найбільш адекватною для позначення цього правозахисного інституту, вважаємо, $\epsilon$ назва - освітній омбудсмен. На відміну від назв шкільний, студентський, університетський омбудсмен, вона охоплює всі відносини у сфері освіти, які виникають на різних рівнях освіти, у закладах освіти різної форми власності й підпорядкування тощо, а також усіх суб'єктів цих відносин - учнів, їхніх батьків, студентів, педагогічних/науково-педагогічних працівників.

Ідеологічне й правове підгрунтя вітчизняного інституту освітнього омбудсмена закладено в міжнародних актах, серед яких: Конвенція про

\footnotetext{
${ }^{2}$ Хомишин І.Ю. Концептуальні питання теорії і практики адміністративно-правового регулювання освіти України в умовах євроінтеграційних процесів : дис. ... докт. юрид. наук : 12.00.07. Львів, 2019. C. 66 .
} 
захист прав людини та основоположних свобод (1950 р.), Декларація прав дитини (1959р.), Конвенція про боротьбу з дискримінацією в галузі освіти (1960р.), Рекомендація про розвиток освіти дорослих, прийнята Генеральною Конференцією ООН з питань освіти, науки і культури на 19-ій сесії (1976р.), Рекомендації МОТ/ЮНЕСКО про статус викладацьких кадрів закладів вищої освіти (1977р.), Конвенція про технічну та професійну освіту (1989р.), Рекомендація № R1281 «Про гендерну рівність у галузі освіти» (ПАРС, 1995 р.), Декларація принципів толерантності (ЮНЕСКО, 1995 р.) тощо.

Так, Принцип 7 Декларації прав дитини проголошує: «Дитина має право на здобуття освіти, яка має бути безоплатною та обов'язковою, щонайменше на початкових рівнях. Дитині має надаватися освіта, яка сприятиме їі загальному культурному розвитку і завдяки якій вона зможе на основі рівних можливостей розвинути свої здібності та особистий світогляд, а також усвідомити моральну та соціальну відповідальність і стати корисним членом суспільства. Дитині має бути забезпечена повна можливість відпочинку та ігор, спрямованих на цілі освіти; суспільство та органи публічної влади повинні докладати зусиль для сприяння реалізації зазначеного права» ${ }^{3}$.

У Конвенції про боротьбу 3 дискримінацією в галузі освіти під дискримінацією розуміють будь-яке розрізнення, виняток, обмеження або перевагу за ознакою раси, кольору шкіри, статі, мови, релігії, політичних чи інших переконань, національного або соціального походження, економічного становища або народження, яке має на меті або наслідком знищення або порушення рівності в галузі освіти. У документі акцентовано, що словом «освіта» охоплюються всі типи і ступені освіти, у тому числі доступ до освіти, рівень і якість навчання, а також умови, в яких воно ведеться (ст. 1), визначено права батьків або законних представників дітей, котрі навчаються (ст. 5), а також зобов'язання держав-сторін Конвенції забезпечити без дискримінації підготовку до викладацької професії (ст. 4)

Ці положення розвиваються у Міжнародному пакті про економічні, соціальні і культурні права, в якому зокрема зазначається, що держави, які беруть участь у Пакті, для повного здійснення права на освіту зобов'язуються: забезпечити для всіх обов'язковість і безоплатність початкової освіти, відкритість і однакову доступність інших рівнів освіти; встановлювати задовільну систему стипендій; постійно поліпшувати

\footnotetext{
${ }^{3}$ Декларація прав дитини : прийнята резолюцією 1386 (XIV) Генеральної Асамблеї ООН від 20.11.1959 року. URL: https://zakon.rada.gov.ua/laws/show/995_384 (дата звернення: 20.05.2020).

${ }^{4}$ Конвенція про боротьбу з дискримінацією в галузі освіти : Міжнародний документ від 14.12.1960 р. URL: http://zakon.rada.gov.ua/laws/show/995_174 (дата звернення: 12.05.2020).
} 
матеріальні умови викладацького персоналу; поважати свободу батьків або законних опікунів щодо реалізації їхніми дітьми права на освіту 5 .

Безпосередньо освіти та рівних можливостей у цій сфері стосується і «правило 6» Стандартних правил забезпечення рівних можливостей для інвалідів (1993р.), відповідно до якого держави мають забезпечувати: аби освіта інвалідів була невід'ємною частиною системи загальної освіти i сприяти інтеграції інвалідів у суспільство та їх навчанню разом 3 іншими учнями; гнучкість навчальних програм, можливість вносити в них доповнення й зміни з урахуванням освітніх потреб інвалідів, високоякісні навчальні матеріали; підготовку на постійній основі викладачів і надання їм підтримки ${ }^{6}$.

Правові основи освітнього омбудсмена в Україні закладає і Протокол № 1 до Конвенції про захист прав людини і основоположних свобод, згідно зі ст. 2 «Право на освіту» якого «нікому не може бути відмовлено у праві на освіту. Держава під час виконання будь-яких функцій, узятих нею на себе в галузі освіти і навчання, поважає право батьків забезпечувати таку освіту i навчання відповідно до їхніх релігійних i світоглядних переконань» ${ }^{7}$.

Важливим $є$ i те, як положення цього Протоколу в частині права на освіту інтерпретує ЄСПЛ. Узагальнення його висновків дало змогу встановити таке: у демократичному суспільстві право на освіту є настільки важливим, що обмежувальне тлумачення першого речення ст. 2 суперечить меті i предмету цього положення (Leyla Şahin проти Туреччини, § 137; Timichev проти Росії, § 64); обмеження права на освіту існують, хоча зі ст. 2 не випливає жодного явного обмеження, такі обмеження не повинні порушувати суті права на освіту і позбавляти його ефективності, повинні бути передбачені законом і переслідувати законну мету, незважаючи на те, що у сфері дії названої статті не існує вичерпного переліку «законних цілей» (Leyla Şahin проти Туреччини, § 154); право на освіту не виключає застосування дисциплінарних заходів, зокрема, тимчасового або остаточного виключення 3 навчального закладу за списування (Sulak проти Туреччини (déc.)) або за погану поведінку (Whitman проти Сполученого Королівства (déc.)); тільки дуже вагомі міркування можуть змусити Суд вважати сумісною з Конвенцією різницю

\footnotetext{
5 Міжнародний пакт про економічні, соціальні і культурні права: Міжнародний документ від 16.12.1966 p. URL: http://zakon.rada.gov.ua/laws/show/995_042 (дата звернення: 26.12.2019).

${ }^{6}$ Резолюція 48/96 Генеральної Асамблеї ООН від 20 грудня 1993 року «Стандартні правила забезпечення рівних можливостей для інвалідів»: ООН; Резолюція, Міжнародний документ від 20.12.1993. URL: https://zakon.rada.gov.ua/laws/show/995_306 (дата звернення: 21.05.2020).

${ }^{7}$ Протокол до Конвенції про захист прав людини і основоположних свобод : Рада Свропи; Протокол, Міжнародний документ від 20.03.1952 p. URL: https://zakon.rada.gov.ua/laws/show/994_535 (дата звернення: 20.05.2020).
} 
у ставленні, засновану виключно на громадянстві, адже право на освіту безпосередньо захищене Конвенцією і стосується громадської послуги особливого характеру, яка служить добробуту не лише осіб, котрі нею користуються, але й усього суспільства, а іiі демократичний вимір стосується інтеграції меншин (Ponomaryovi проти Болгарії) тощо ${ }^{8}$.

Роль певного каталізатора у процесі становлення моделі омбудсмена, у тому числі освітнього, в Україні й усьому світі відіграли Паризькі принципи, якими передбачено створення національних установ, призначених заохочувати і сприяти захисту прав людини, з широкими повноваженнями, чітко викладеними в конституційному або законодавчому акті, який визначає склад і компетенції такої установи 9

Згадані вище положення міжнародних та європейських актів знайшли закріплення у вітчизняному законодавстві, передусім у Конституції України, згідно зі ст. 53 якої: «Повна загальна середня освіта $\epsilon$ обов'язковою. Держава забезпечує доступність і безоплатність дошкільної, повної загальної середньої, професійно-технічної, вищої освіти в державних і комунальних навчальних закладах; розвиток дошкільної, повної загальної середньої, позашкільної, професійно-технічної, вищої і післядипломної освіти, різних форм навчання; надання державних стипендій та пільг учням і студентам. Громадяни мають право безоплатно здобути вищу освіту в державних і комунальних навчальних закладах на конкурсній основі. Громадянам, які належать до національних меншин, відповідно до закону гарантується право на навчання рідною мовою чи на вивчення рідної мови у державних і комунальних навчальних закладах або через національні культурні товариства» ${ }^{10}$.

Однією 3 гарантій конституційного права на освіту та прав у сфері освіти стало закріплення у Законі України «Про освіту» ${ }^{11}$ (далі - Закон «Про освіту») ст. 73 «Інститут освітнього омбудсмена» 3 конкретизацією правового статусу відповідної посадової особи у Постанові Кабінету Міністрів України «Про деякі питання освітнього омбудсмена» ${ }^{12}$, якою

\footnotetext{
${ }^{8}$ Довідник із застосування статті 2 «раво на освіту» Протоколу № 1 до Європейської Конвенції 3 прав людини. Рада Європи / Свропейський суд 3 прав людини, 2017. С. 6, 7, 8, 9. URL: https://www.echr.coe.int/Documents/Guide_Art_2_Protocol_1_UKR.pdf (дата звернення: 21.05.2020).

${ }^{9}$ Принципи, які стосуються статусу національних установ, що займаються заохоченням і захистом прав людини (Паризькі принципи). Додаток до резолюції 48/134 Генеральної Асамблеї ООН : Міжнародний документ від 20.12.1993 p. URL: http://notorture.org.ua/wp-content/uploads/2017/10/Parizkiprintsipi.pdf (дата звернення: 22.05.2020).

10 Конституція України : станом на 01.01.2020 p. URL: https://zakon.rada.gov.ua/laws/show/254к/96-вр (дата звернення: 15.05.2020).

11 Про освіту : Закон України від 05.09.2017 p. № 2145-VIII. URL: https://zakon.rada.gov.ua/ laws/show/2145-19 (дата звернення: 21.05.2020).

${ }^{12}$ Про деякі питання освітнього омбудсмена : Постанова Кабінету Міністрів України від 06.06.2018 р. № 491. URL: https://zakon.rada.gov.ua/laws/show/491-2018-п (дата звернення: 25.05.2020).
} 
затверджено «Положення про освітнього омбудсмена» ${ }^{13}$ (далі Положення) i «Порядок та умови звернення до освітнього омбудсмена» 14 (далі - Порядок). Переліченими нормативно-правовими актами у своїй роботі керується і сам освітній омбудсмен.

\section{2. Мета, завдання та принципи діяльності освітнього омбудсмена}

Метою діяльності освітнього омбудсмена, виходячи зі змісту ч. 1 ст. 73 Закону «Про освіту», є забезпечення належних умов для реалізації права особи на освіту в системі освіти, що згідно з ч. 1 ст. 3 Закону «Про освіту» охоплює:

- право на якісну освіту;

- право на доступну освіту, що за ст.ст. 3, 13 Закону «Про освіту» передбачає створення в Україні рівних умов доступу до освіти й означає таке: ніхто не може бути обмежений у праві на здобуття освіти; право на освіту гарантується незалежно від віку, статі, раси, здоров'я, інвалідності, громадянства, національності, політичних, релігійних, інших переконань, кольору шкіри, місця проживання, мови спілкування, походження, соціального і майнового стану, судимості, інших обставин та ознак тощо;

- право здобувати освіту впродовж усього життя, що згідно з ч. 3 ст. 3, ст.ст. 8, 9 Закону «Про освіту» може реалізовуватися шляхом їі здобуття на різних рівнях (дошкільна, повна загальна середня, позашкільна, професійна/ професійно-технічна, фахова передвища, вища освіта та освіта дорослих), у різних видах (формальна, неформальна, інформальна освіта) та у різних формах (інституційна: очна (денна, вечірня), заочна, дистанційна, мережева; індивідуальна: екстернатна, сімейна/домашня, педагогічний патронаж, на робочому місці/на виробництві; дуальна);

- право на безоплатну освіту, яка здобувається особою за рахунок коштів державного та/або місцевих бюджетів згідно із законодавством, у випадках і порядку, визначених Конституцією та законами України (ч. 3 ст. 1 Закону «Про освіту»). Згідно з ч. 9 ст. 3 Закону «Про освіту», право на освіту не може бути обмежене законом, разом із тим закон може встановлювати особливі умови доступу до певного рівня освіти, спеціальності (професіі).

Мету діяльності освітнього омбудсмена деталізовано через основні завдання цієї посадової особи, визначені у Положенні. Згідно 3 п. 8 документа такими завданнями є: 1) сприяння реалізації державної

\footnotetext{
13 Положення про освітнього омбудсмена : затв. Постановою Кабінету Міністрів України від 06.06.2018 р. № 491. URL: https://zakon.rada.gov.ua/laws/show/491-2018-п (дата звернення: 25.05.2020).

14 Порядок та умови звернення до освітнього омбудсмена : затв. Постановою Кабінету Міністрів України від 06 червня 2018 р. № 491. URL: https://zakon.rada.gov.ua/laws/show/491-2018-п (дата звернення: 21.05.2020).
} 
політики, спрямованої на забезпечення права людини на здобуття якісної та доступної освіти; 2) здійснення заходів щодо додержання законодавства про освіту; 3) вжиття заходів для забезпечення належних умов для рівного доступу до здобуття освіти; 4) сприяння впровадженню інклюзивної форми навчання; 5) сприяння виконанню Україною міжнародних зобов'язань щодо додержання в Україні прав людини на освіту; 6) співпраця та взаємодія з $\mathrm{MOH}$ та іншими центральними органами виконавчої влади, місцевого самоврядування, закладами освіти тощо.

Освітній омбудсмен має особливий правовий статус. Так, згідно 3 п.п. 1-2 Положення це - посадова особа, на яку Кабмін покладає виконання завдань із захисту прав у сфері освіти, яка призначається на посаду та звільняється 3 посади Кабміном за поданням Міністра освіти і науки строком на п’ять років без права повторного призначення. Отже, освітній омбудсмен в Україні діє від імені та в площині виконавчої влади, на відміну від Уповноваженого Верховної Ради України з прав людини, який діє від законодавчої влади, або Уповноваженого Президента України з прав дітей, який здійснює правозахисну діяльність від імені Глави держави.

У наших попередніх працях ми зазначали, що статус освітнього омбудсмена не визначений однозначно у законодавстві. Останнє не дає чіткого розуміння, яким $\epsilon$ місце освітнього омбудсмена та Служби освітнього омбудсмена (далі - Служба) у системі виконавчої влади. Так, призначається особа на цю посаду Кабміном. 3 правом дорадчого голосу освітній омбудсмен бере участь у засіданнях Кабміну під час розгляду питань, що належать до його компетенції (п. 10 Положення). При цьому Положення про Службу освітнього омбудсмена, іiі структуру, кошторис, штатний розпис на відповідний рік та зміни до них затверджує МОН України (п. 23 Положення про освітнього омбудсмена). Такий підхід викликає запитання організаційного характеру: освітній омбудсмен та його Служба є підрозділом у структурі Кабміну чи МОН України, або освітній омбудсмен - у структурі Кабміну, а його Служба - у структурі $\mathrm{MOH}$ України, а, можливо, освітній омбудсмен - окрема одиниця у системі виконавчої влади? Крім того, законодавство не передбачає посаду заступника освітнього омбудсмена, уведення якої доцільно хоча б у контексті пошуку відповіді на питання про те, хто буде виконувати відповідні обов'язки у період тимчасової відсутності освітнього омбудсмена. Можливим $є$ їх покладання на керівника служби освітнього омбудсмена, однак законодавство не містить такої вказівки ${ }^{15}$.

\footnotetext{
${ }^{15}$ Рябовол Л.Т. Основи правового статусу освітнього омбудсмена в Україні. Наукові записки Кіровоградського державного педагогічного університету імені Володимира Винниченка. Серія «Право». 2019. Вип. 7. С. 5.
} 
До кандидатури на посаду освітнього омбудсмена висуваються досить серйозні вимоги, а саме: наявність у особи громадянства України; проживання в Україні останні п'ять років; наявність вищої освіти; наявність досвіду роботи у сфері освіти або науки не менше п'яти років; вільне володіння державною мовою. Крім того, не може бути освітнім омбудсменом особа, яка має судимість, обмежена у дієздатності або визнана недієздатною за рішенням суду (п.п. 3-4 Положення). Перелічені вимоги $є$ цілком обгрунтованими. Так, наявність громадянства України $\epsilon$ важливою з огляду на те, що свою діяльність ця посадова особа здійснює у сфері державного управління, а проживання в Україні останні п'ять років та наявність досвіду роботи у сфері освіти або науки не менше п'яти років забезпечить обізнаність освітнього омбудсмена у проблемах в освітній галузі, у тому числі щодо реалізації прав у цій сфері. Водночас вимогу щодо наявності вищої освіти, на наш погляд, доцільно деталізувати i вказати на наявність вищої педагогічної та/або вищої юридичної освіти. Ідеальним видається поєднання педагогічної та юридичної освіти, що дало б змогу призначеній на цю посаду особі вільно орієнтуватися у педагогічних та правових основах провадження освітньої діяльності та реалізації освітнього процесу, а також розуміти різні аспекти його організації у закладах освіти і науки.

Аналіз законодавства та наукової літератури дав змогу визначити принципи діяльності освітнього омбудсмена. Насамперед це - принцип гуманізму, який визнає людину з іiі правами і свободами як найвищу цінність, а освітній омбудсмен покликаний сприяти у реалізації права особи на освіту. У своїй діяльності освітній омбудсмен керується Конституцією і законами України, отже, принципом його діяльності $\epsilon$ конституційність і законність. На неперервність і постійність як на вихідні засади його діяльності вказує те, що законодавством визначено строк повноважень та процедуру призначення освітнього омбудсмена на посаду. Ще одним принципом $є$ те, що освітній омбудсмен - субсидіарний елемент правозахисного механізму, який доповнює діяльність інших органів, посадових осіб, громадських організацій щодо захисту права на освіту.

Основи правового статусу освітнього омбудсмена, закріплені у вітчизняному законодавстві, повною мірою узгоджується з усталеним у світовій практиці підходом, згідно 3 яким будь-який омбудсмен $\epsilon$ незалежним i самостійним під час здійснення своїх повноважень. Незалежність освітнього омбудсмена забезпечується дотриманням таких вимог: втручання органів державної влади та місцевого самоврядування в його діяльність є неприпустимим; освітній омбудсмен не може брати участь у будь-якій політичній діяльності (п. 6 Положення), є політично 
нейтральною посадовою особою; освітній омбудсмен і його Служба мають кошторис, що забезпечує їх матеріально-фінансову незалежність; освітній омбудсмен не має права суміщати свою посаду з будь-якою посадою в органі державної влади або органі місцевого самоврядування, зі статусом народного депутата України, депутата Верховної Ради АРК, обласної, районної, міської, районної у місті, сільської, селищної ради, 3 підприємницькою діяльністю, обіймати будь-яку іншу оплачувану посаду, виконувати будь-яку іншу оплачувану роботу або отримувати іншу заробітну плату (за винятком провадження викладацької, наукової чи творчої діяльності й отримання винагороди за неї), а також входити до складу керівного органу чи наглядової ради юридичної особи, що має на меті одержання прибутку (п. 5 Положення). Дотримання вимог щодо незалежності й несумісності зокрема сприяє неупередженості та об'єктивності освітнього омбудсмена у процесі розгляду ним скарг про порушення прав у сфері освіти.

3 питань, що належать до його компетенції, освітній омбудсмен взаємодіє з МОН, іншими центральними органами виконавчої влади, органами місцевого самоврядування, закладами освіти всіх рівнів незалежно від форми власності і підпорядкування, органами управління освітою, правоохоронними органами. Забезпечувати цю взаємодію, згідно 3 пп. 5 п. 15 Положення, має Служба освітнього омбудсмена. У процесі виконання завдань, покладених на освітнього омбудсмена, він також взаємодіє 3 неурядовими громадськими організаціями (пп. 6 п. 8 Положення), крім того, до розгляду скарг, з якими до нього звертаються заявники, можуть залучатися представники громадськості (п. 17 Порядку). Це дає змогу характеризувати такий інститут як державно-громадський за своїм характером (характером своєї діяльності). Взаємодія 3 різними суб'єктами державного механізму й громадянського суспільства разом 3 оприлюдненням доповідей про результати своєї діяльності та розробкою рекомендацій позначає його як відкритий інститут, отже, ще один принцип діяльності освітнього омбудсмена - відкритість/транспарентність.

Освітній омбудсмен має право отримувати від закладів освіти та органів управління освітою інформацію (у тому числі з обмеженим доступом), необхідну для виконання ним своїх функцій, а за результатами проведених перевірок надавати рекомендації закладам освіти, органам управління освітою. Служба освітнього омбудсмена під час розгляду питань, що належать до їі компетенції, може залучати представників закладів освіти всіх рівнів незалежно від форми власності та підпорядкування за погодженням з їх керівниками (ч. 4 ст. 73 Закону «Про освіту»; пп. 2 п. 16 
Положення), що загалом дає змогу характеризувати відносини освітнього омбудсмена з «підконтрольними» йому суб'єктами як партнерські.

Діяльність освітнього омбудсмена грунтується також на принципі, згідно з яким забезпечується конфіденційність розслідувань, які він та його Служба проводять у межах виконання покладених на них завдань. Реалізується цей принцип й у тому контексті, що представникам громадськості, які залучаються до перевірки скарг, надаються матеріали із знеособленими персональними даними заявників, крім того, нікому не дозволяється розголошувати відомості стосовно заявника та його скарги (п.п. 17, 26 Порядку).

\section{3. Функціональне призначення освітнього омбудсмена в Украйні}

Суспільне призначення освітнього омбудсмена розкривається через його функції. Основною з них є правозахисна, яка інтегрує діяльність із захисту та відновлення порушеного права, для виконання якої держава наділяє цю посадову особу та його Службу необхідними повноваженнями. У межах виконання правозахисної функції як основного напряму своєї діяльності освітній омбудсмен має певні повноваження - прямі (безпосередні) засоби впливу на «підконтрольних» йому суб'єктів та опосередковані можливості сприяти покращенню стану реалізації прав у сфері освіти.

До безпосередніх засобів можна віднести реагування на скарги, їх розгляд та перевірку фактів, викладених у них, як основну форму роботи освітнього омбудсмена (ч. 4 ст. 73 Закону «Про освіту»; п. 9 Положення). Суб'єктами, які мають право звертатися до нього зі скаргами про порушення прав у сфері освіти, є: здобувачі освіти, їхні батьки, законні представники, а також педагогічні, науково-педагогічні i наукові працівники (п. 3 Порядку).

У попередніх працях ${ }^{16}$ ми вже розглядали процесуальні, формальні та змістові вимоги до скарги про порушення прав у сфері освіти, яка подається заявником до освітнього омбудсмена. Їх визначено у п.п. 4-14 Порядку, зокрема, встановлено строк давності - скарга подається протягом року після виявлення порушення прав. До неї можуть додаватися копії документів, завірені в установленому порядку, які підтверджують інформацію, зазначену у скарзі. Визначено види скарги: 1) залежно від суб'єкта подання: індивідуальна, яка подається окремою особою;

\footnotetext{
${ }^{16}$ Рябовол Л.Т. Освітній омбудсмен як елемент правозахисного механізму в Україні. Правові засади діяльності правоохоронних органів : збірник статей, тез доповідей та повідомлень (за матеріалами VI Міжнародної науково-практичної конференції (Харків, 5-6 грудня, 2019 р)). Харків, 2019. С. 107; Рябовол Л.Т. Скарга як форма звернення до освітнього омбудсмена. Теоретичні та практичні проблеми реалізайї норм права : матеріали $\mathrm{V}$ міжнародної науково-практичної конференції (Кременчук, 7-8 грудня 2019 р.). Кременчук, 2019. С. 24.
} 
колективна, подана групою осіб; 2) за формою подання скарги - може подаватися: а) особисто або через уповноважену особу, за умови, що іiі повноваження оформлені відповідно до законодавства; б) у письмовій формі (надсилається поштою на адресу Служби освітнього омбудсмена чи подається особисто) або електронній (надсилається на електронну адресу Служби із використанням засобів електронного зв'язку).

У скарзі зазначаються: прізвище, ім'я та по батькові заявника, місце його проживання, вимоги про поновлення порушених прав i захист законних інтересів; у скарзі в електронній формі, крім того, - електронна адреса, на яку заявникові може бути надіслано відповідь, або відомості про інші засоби зв'язку з ним; скарга повинна бути підписана заявником із зазначенням дати. Важливо, якщо заявник не зазначає у скарзі свого прізвища, імені, по батькові, місця проживання або не надає інших відомостей, необхідних для прийняття обгрунтованого рішення, скарга реєструється як анонімна, залишається без розгляду і повертається заявнику з відповідним обгрунтуванням протягом десяти робочих днів 3 дня іiї надходження. Повторні скарги до освітнього омбудсмена від одного i того самого заявника, 3 одного і того самого питання відповідно до Порядку не розглядаються. Виходячи зі змісту п. 15 Порядку, можна визначити види строків розгляду скарг до освітнього омбудсмена, а саме: звичайний строк - не довше одного календарного місяця 3 дня надходження скарги; надзвичайний - строк, необхідний для розгляду скарги, якщо у місячний строк вирішити порушені у скарзі питання неможливо; граничний/максимальний - не більш як 45 календарних днів.

Під час розгляду скарги Служба вживає заходи для об'єктивного вирішення поставлених заявником питань, з'ясовує причини та умови, що призводять до порушення прав та законних інтересів заявників, а саме: в разі потреби одержує від заявника матеріали, необхідні для перевірки фактів, викладених у скарзі; спілкується із заявником, з'ясовує всі порушені питання; надсилає запити щодо отримання необхідної для розгляду скарги інформації; залучає представників громадськості (п.п. 16, 17 Порядку). Відкритим залишається питання, чи має право освітній омбудсмен здійснювати перевірки за власною ініціативою, наприклад, у зв'язку з отриманням інформації про порушення права на освіту із засобів масової інформації, соціальних мереж, а не тільки реагувати на звернення до нього. Нормативне закріплення такого повноваження суттєво розширило б його потенціал щодо забезпечення належних умов для реалізації права на освіту. 
У наших попередніх працях ${ }^{17}$ ми вже зазначали, що особливою $є$ місія освітнього омбудсмена щодо викорінення такого ганебного явища у закладах освіти, як булінг (цькування). До відповідних повноважень віднесено: здійснення перевірок заяв про випадки булінгу (цькування) в закладі освіти, повноту і своєчасність заходів реагування на такі випадки 3 боку педагогічних, науково-педагогічних, наукових працівників, керівництва та засновника закладу освіти; проведення аналізу заходів для надання соціальних та психолого-педагогічних послуг здобувачам освіти, які постраждали від булінгу (цькування), стали його свідками або вчинили булінг (цькування) (абз. 3-4 ч. 4 ст. 73 Закону «Про освіту»). Нині повноваження освітнього омбудсмена полягають не лише у розгляді й перевірці відповідних заяв, але й у вивченні стану роботи щодо соціальнопсихологічної реабілітації осіб, причетних до згаданого явища. Важливим $\epsilon$ також його повноваження представляти інтереси особи у суді (абз. 9 ч. 4 ст. 73 Закону «Про освіту»). Слід зазначити, що в цій частині вітчизняне законодавство повністю відповідає Конвенції про права дитини. Згідно зі ст. 16 документа «жодна дитина не може бути об’єктом свавільного або незаконного втручання в здійснення ii права на особисте і сімейне життя, недоторканність житла, таємницю кореспонденції або незаконного посягання на іiі честь і гідність. Дитина має право на захист закону від такого втручання або посягання» ${ }^{18}$.

До опосередкованих засобів впливу на стан дотримання прав у сфері освіти можна віднести те, що за результатами проведених перевірок освітній омбудсмен має право повідомляти правоохоронні органи про виявлені факти порушення законодавства, а також звертатися до органів державної влади, правоохоронних органів щодо виявлених фактів порушення права людини на освіту та законодавства у сфері освіти (абз. 5-7 ч. 4 ст. 73 Закону «Про освіту», п. 9 Положення).

Загалом, вітчизняне законодавство в частині визначення функцій освітнього омбудсмена повністю відповідає згадуваним вище Паризьким принципам, згідно з якими основними функціями, що покладаються на національні інститути з прав людини, є: консультативно-рекомендаційна, сутність якої - у розробці пропозицій, рекомендацій з питань захисту прав людини та наданні їх у консультативному порядку уряду, парламенту та

\footnotetext{
${ }^{17}$ Рябовол Л.Т. Основи правового статусу освітнього омбудсмена в Україні. Наукові записки Кіровоградського державного університету імені Володимира Винниченка. Серія «Право». 2019. Вип. 7. С. 6; Рябовол Л.Т. Освітній омбудсмен як елемент правозахисного механізму в Україні. Правові засади діяльності правоохоронних органів : збірник статей, тез доповідей та повідомлень (за матеріалами VI Міжнародної науково-практичної конференції (Харків, 5-6 грудня, 2019 р)). Харків, 2019. C. 107.

18 Конвенція про права дитини : ООН; Конвенція, Міжнародний документ від 20.11.1989 p. URL: https://zakon.rada.gov.ua/laws/show/995_021 (дата звернення: 25.05.2020).
} 
будь-якому іншому компетентному органу чи посадовій особі; аналітична аналіз чинного законодавства, законопроєктів і правозастосовної практики щодо реалізації й дотримання прав людини; інформаційно-просвітницька; комунікативна - співробітництво 3 національними та міжнародними інституціями, призначення яких - у захисті прав та законних інтересів людини і громадянина; контрольна (без юрисдикційних повноважень) ${ }^{19}$.

Оскільки до основних завдань Служби, згідно з пп. 1, 3 п. 15 Положення, віднесено й узагальнення практики застосування законодавства у сфері освіти, розроблення пропозицій щодо вдосконалення актів законодавства в цій сфері та проведення аналізу й узагальнення інформації, що міститься у скаргах, поданих освітньому омбудсмену, його функцією є інформаційноаналітична. Крім того, ця посадова особа уповноважена надавати консультації здобувачам освіти, їхнім батькам, законним представникам та особам, які навчають (абз. 8 ч. 4 ст. 73 Закону), заявнику (п. 20 Порядку), отже, виконує консультативну, певною мірою правопросвітницьку/ правороз'яснювальну функцію.

У контексті визначення принципів діяльності освітнього омбудсмена ми вже вказували, що цей інститут за характером своєї діяльності є державногромадським. Так, законодавство передбачає, що у процесі реалізації своїх повноважень освітній омбудсмен тісно співпрацює з різними державними органами та органами місцевого самоврядування, а до його основних завдань віднесена співпраця та взаємодія з питань, що належать до його компетенції, з МОН України та іншими центральними органами виконавчої влади, місцевого самоврядування, закладами освіти всіх рівнів незалежно від форми власності і підпорядкування, органами управління освітою, правоохоронними органами, міжнародними організаціями, неурядовими громадськими організаціями (ч. 6 п. 8 Положення). Відповідно до законодавства освітній омбудсмен тісно співпрацює також і iз суспільними/громадськими інституціями, у тому числі міжнародними організаціями, неурядовими громадськими організаціями. Під час розгляду скарги служба освітнього омбудсмена серед заходів, які вона вживає для об'єктивного вирішення поставлених заявником питань, залучає i представників громадськості (п.п. 16, 17 Порядку).

Завдяки участі в засіданнях Кабміну, МОН України, взаємодії 3 управліннями/відділами освіти, інститутами громадянського суспільства освітній омбудсмен постає як своєрідний посередник між суб'єктами права на освіту й державними органами різних рівнів, уповноважених

\footnotetext{
19 Национальные правозащитные учреждения: история, принципы, роль и функции. Серия материалов по вопросам профессиональной подготовки. № 4. Организация Объединенных Наций (Центр по правам человека). Нью-Йорк; Женева, 2010. С. 4-6.
} 
забезпечувати реалізацію цього права. Шляхом залучення громадськості до розгляду питань у сфері освіти і загалом своєю діяльністю ця посадова особа дає змогу підтримувати постійні прямі та зворотні зв'язки між владою і суспільством, державою та особою, таким чином, сприяє у забезпеченні нової якості освіти, у тому числі й управління нею. Як державно-громадський інститут освітній омбудсмен має суттєвий потенціал щодо забезпечення умов для реалізації права на освіту i підвищення якості освіти. Однак поки що наявні проблеми, які не дають змогу повною мірою реалізувати цей потенціал, а саме: консервативність $і$ закритість вітчизняної системи освіти, не досить швидке й адекватне іiі реагування на виклики сьогодення; пролонгація традиційного для радянського й пострадянського періодів підходу, згідно з яким освіта, отже, і управління освітою, це - сфера відповідальності держави, а не суспільства; здійснення громадськістю лише перших кроків щодо участі у вирішенні питань освіти; неготовність освітян, у тому числі управлінців у сфері освіти, до тісної співпраці з інститутами громадянського суспільства.

\section{ВИСНОВКИ}

Інститут омбудсмена нині - невід'ємний компонент правозахисного механізму демократичної держави, своєрідний посередник між людиною та органами публічної влади, призначення якого - гарантувати права i свободи першої на найвищому державному рівні. Мережу омбудсменів в Україні становить і освітній омбудсмен. Правові засади організації та функціонування цього інституту закладено у міжнародних актах i вітчизняному законодавстві. Особливість правового статусу освітнього омбудсмена полягає у тому, що він поєднує риси державного органу і громадської інституції, має державно-громадський характер. Так, він наділений певними повноваженнями, виконувати які має у тісній взаємодії не лише 3 органами державної влади та місцевого самоврядування, але й громадянським суспільством.

Принципами діяльності освітнього омбудсмена є: гуманізм; законність і конституційність; неперервність функціонування; субсидіарність; політична нейтральність; об'єктивність у розгляді скарг про порушення прав у сфері освіти; транспарентність; партнерські відносини 3 «підконтрольними» суб'єктами; конфіденційність розслідувань. Освітній омбудсмен у різних напрямах впливає на стан дотримання прав у сфері освіти, проте основною $\epsilon$ його правозахисна функція. На іiі виконання ця посадова особа наділена певними повноваженнями як безпосередніми засобами впливу на «підконтрольних» йому суб'єктів, так і опосередкованими можливостями сприяти покращенню стану реалізації прав у сфері освіти. Освітній 
омбудсмен здійснює також інформаційно-аналітичну, консультативну, правопросвітницьку функції, має значний потенціал щодо забезпечення умов для реалізації права на освіту та підвищення якості освіти, однак поки що є певні проблеми, які ускладнюють його реалізацію повною мірою.

\section{АНОТАЦІЯ}

У статті правовий статус освітнього омбудсмена розглянуто у двох аспектах: 1) як сукупність нормативно-правових актів, якими визначено місце і роль цього інституту у державному механізмі; 2) як сукупність сутнісних ознак цього інституту - мети, завдань, принципів діяльності, порядку призначення та звільнення з посади, організаційної структури, функцій та повноважень, порядку взаємодії з органами державної влади, інститутами громадянського суспільства, міжнародними організаціями, які діють у сфері захисту прав людини загалом і права на освіту зокрема, відповідальності за порушення законодавства й невиконання посадових обов'язків, закріплених у нормативно-правових актах. Визначено міжнародні та вітчизняні нормативно-правові акти, які заклали правове підгрунтя інституту освітнього омбудсмена в Україні. 3'ясовано, що особливості правового статусу цієї посадової особи зумовлені державногромадським характером самої інституції. Констатовано, що метою діяльності освітнього омбудсмена $\epsilon$ забезпечення належних умов для реалізації права особи на освіту в системі освіти. До принципів діяльності освітнього омбудсмена віднесено: гуманізм; законність і конституційність; неперервність функціонування; субсидіарність; політичну нейтральність; об'єктивність у розгляді скарг про порушення прав у сфері освіти; транспарентність; партнерські відносини з «підконтрольними» суб' єктами; конфіденційність розслідувань. Встановлено, що основними функціями освітнього омбудсмена $\epsilon$ : правозахисна, інформаційно-аналітична, консультативна, правопросвітницька, та розкрито їх сутність.

\section{ЛІТЕРАТУРА}

1. Тодика Ю.Н., Марцеляк О.В. Інститут омбудсмена: світові моделі і досвід. Вісник Академії правових наук Украӥни. 2008. № 2(13). С. 57-66.

2. Хомишин І.Ю. Концептуальні питання теорії i практики адміністративно-правового регулювання освіти України в умовах євроінтеграційних процесів : дис. ... докт. юрид. наук : 12.00.07. Львів, 2019. $510 \mathrm{c}$.

3. Декларація прав дитини: прийнята резолюцією 1386 (XIV) Генеральної Асамблеї ООН від 20.11.1959 року. URL: https:// zakon.rada.gov.ua/laws/show/995_384 (дата звернення: 20.05.2020). 
4. Конвенція про боротьбу 3 дискримінацією в галузі освіти : Міжнародний документ від 14.12.1960 p. URL: http://zakon.rada.gov.ua/ laws/show/995_174 (дата звернення: 12.05.2020).

5. Міжнародний пакт про економічні, соціальні і культурні права: Міжнародний документ від 16.12.1966 p. URL: http://zakon.rada.gov.ua/ laws/show/995_042 (дата звернення: 26.12.2019).

6. Резолюція 48/96 Генеральної Асамблеї ООН від 20 грудня 1993 року «Стандартні правила забезпечення рівних можливостей для інвалідів»: OOH; Резолюція, Міжнародний документ від 20.12.1993. URL: https://zakon.rada.gov.ua/laws/show/995_306 (дата звернення: 21.05.2020).

7. Протокол до Конвенції про захист прав людини і основоположних свобод : Рада Європи; Протокол, Міжнародний документ від 20.03.1952 p. URL: https://zakon.rada.gov.ua/laws/show/994_535 (дата звернення: 20.05.2020).

8. Довідник із застосування статті 2 «Право на освіту» Протоколу № 1 до Європейської Конвенції з прав людини. Рада Європи / Європейський суд 3 прав людини, 2017. 21 с. URL: https://www.echr.coe.int/Documents/ Guide_Art_2_Protocol_1_UKR.pdf (дата звернення: 21.05.2020).

9. Принципи, які стосуються статусу національних установ, що займаються заохоченням і захистом прав людини (Паризькі принципи). Додаток до резолюції 48/134 Генеральної Асамблеї ООН : Міжнародний документ від 20.12.1993 p. URL: http://notorture.org.ua/wp-content/uploads/ 2017/10/Parizki-printsipi.pdf (дата звернення: 22.05.2020).

10. Конституція України : станом на 01.01.2020 p. URL: https://zakon.rada.gov.ua/laws/show/254к/96-вр (дата звернення: 15.05.2020).

11. Про освіту: Закон України від 05.09 .2017 p. № 2145-VIII. https://zakon.rada.gov.ua/laws/show/2145-19 (дата звернення: 21.05.2020).

12. Про деякі питання освітнього омбудсмена : Постанова Кабінету Міністрів України від 06.06.2018 p. № 491. URL: https://zakon.rada.gov.ua/ laws/show/491-2018-п (дата звернення: 25.05.2020).

13. Положення про освітнього омбудсмена : затв. Постановою Кабінету Міністрів України від 06.06.2018 p. № 491. URL: https://zakon.rada.gov.ua/ laws/show/491-2018-п (дата звернення: 25.05.2020).

14. Порядок та умови звернення до освітнього омбудсмена : затв. постановою Кабінету Міністрів України від 06 червня 2018 р. № 491. URL: https://zakon.rada.gov.ua/laws/show/491-2018-п (дата звернення: 21.05.2020).

15. Рябовол Л.Т. Основи правового статусу освітнього омбудсмена в Україні. Наукові записки Кіровоградського державного університету імені Володимира Винниченка. Серія «Право». 2019. Вип. 7. С. 4-8. DOI: https://doi.org/10.36550/2522-9230.2019.7.1. 
16. Рябовол Л.Т. Освітній омбудсмен як елемент правозахисного механізму в Україні. Правові засади діяльності правоохоронних органів : збірник статей, тез доповідей та повідомлень (за матеріалами VI Міжнародної науково-практичної конференції (Харків, 5-6 грудня, 2019 р)). Харків, 2019. С. 106-109; Рябовол Л.Т. Скарга як форма звернення до освітнього омбудсмена. Теоретичні та практичні проблеми реалізачіï норм права : матеріали $\mathrm{V}$ міжнародної науково-практичної конференції (Кременчук, 7-8 грудня 2019 р.). Кременчук, 2019. С. 23-25.

17. Рябовол Л.Т. Основи правового статусу освітнього омбудсмена в Україні. Наукові записки Кіровоградського державного університету імені Володимира Винниченка. Серія «Право». 2019. Вип. 7. С. 6; Рябовол Л.Т. Освітній омбудсмен як елемент правозахисного механізму в Україні. Правові засади діяльності правоохоронних органів : збірник статей, тез доповідей та повідомлень (за матеріалами VI Міжнародної науковопрактичної конференції (Харків, 5-6 грудня, 2019 р)). Харків, 2019. C. $106-109$.

18. Конвенція про права дитини: ООН; Конвенція, Міжнародний документ від 20.11.1989 p. URL: https://zakon.rada.gov.ua/laws/show/ 995_021 (дата звернення: 25.05.2020).

19. Национальные правозащитные учреждения: история, принципы, роль и функции. Серия материалов по вопросам профессиональной подготовки. № 4. Организация Объединённых Наций (Центр по правам человека). Нью-Йорк; Женева, 2010. 226 с.

\section{Information about author:}

Riabovol L. T.,

Doctor of Pedagogical Sciences, Professor,

Professor of the State-legal Disciplines and Administrative Law Department Volodymyr Vynnychenko Central Ukrainian State Pedagogical University 1, Shevchenka Str., Kropyvnytskyi, 25000, Ukraine 